\title{
INFLUENCE OF MINERAL AND ORGANIC NITROGEN FERTILIZERS ON GROWTH AND YIELD OF SOME WHEAT VARIETIES AND SOME SOIL PROPERTIES - NORTH DELTA .
}

Khafagy, E.E.E.

Soils, Water and Environment Research Institute, Agricultural Research Center, Giza, Egypt.

\begin{abstract}
Two field experiments were conducted at the Experimental Research Station in El-Serw, Agricultural Research Center during the seasons 2012/2013 and 2013/2014 to study the effect of mineral nitrogen and organic nitrogen of compost combination treatments on grain and straw yield and N, P, K- uptake in grain and straw of some wheat varieties. The experiments were carried out in a split plot design with three replicates. Main plots were assigned to three wheat cultivars i.e., Sakha 93, Gemmiza 9 and Gemmiza 10. The sub main plots were devoted to mineral nitrogen and compost combination treatments as follows: $100 \%$ inorganic nitrogen $\left(90 \mathrm{~kg} \mathrm{fed}^{-1}\right), 75 \%$ inorganic nitrogen $\left(67.5 \mathrm{~kg} \mathrm{fed}^{-1}\right)+25 \%$ organic nitrogen $\left(22.5 \mathrm{~kg} \mathrm{fed}^{-1}\right)$, $50 \%$ inorganic nitrogen $\left(45.0 \mathrm{~kg} \mathrm{fed}^{-1}\right)+50 \%$ organic nitrogen $\left(45.0 \mathrm{~kg} \mathrm{fed}^{-1}\right), 25 \%$ inorganic nitrogen $\left(22.5 \mathrm{~kg} \mathrm{fed}^{-1}\right)+75 \%$ organic nitrogen $\left(67.5 \mathrm{~kg} \mathrm{fed}^{-1}\right)$ and $100 \%$ organic nitrogen $\left(90 \mathrm{~kg} \mathrm{fed}^{-1}\right)$. Obtained results showed that the greatest values of wheat grain , straw yields , N, P and K uptake in both grain and straw were those of Gemmeza 10, Gemmeza 9 and Sakha 93, respectively and $100 \%$ inorganic nitrogen, $75 \%$ inorganic nitrogen $+25 \%$ organic nitrogen, $50 \%$ inorganic nitrogen $+50 \%$ organic nitrogen, $25 \%$ inorganic nitrogen $+75 \%$ organic nitrogen and $100 \%$ organic nitrogen, respectively. 100\% inorganic nitrogen for Gemmiza 10 gave the highest wheat grain and straw yields and $\mathrm{N}, \mathrm{P}$, and $\mathrm{K}$ uptake in grain and straw. While, applying $75 \%$ inorganic nitrogen with $25 \%$ organic nitrogen produced economic wheat grain and straw yields for Sakha 93 only. So, $25 \%$ inorganic nitrogen could be saved, and environmental pollution with mineral- $\mathrm{N}$ fertilizers could also be reduced. As well as improved soil properties i.e increased hydraulic conductivity,on the contrary,bulk density,Ece and $\mathrm{pH}$ values were decreased.
\end{abstract}

Keywords: wheat, organic fertilizer, compost, nitrogen fertilizer, fertilizer, cultivars, varieties, soil properties, North Delta.

\section{INTRODUCTION}

Wheat (Triticum aestivum,L.) is one of the most important nutritional cereal crops in Egypt and all over the world. Wheat production is not sufficient for local consumption in Egypt. Great efforts have been made to achieve suitable agronomic practices for obtaining maximum productivity of different wheat varieties with optimum quality properties.Objective of, this study is to evaluate the new promising cultivars in comparison with the old traditional ones for scoping light on the best cultivars that can be used under the environmental conditions of the study region. El-Metwally et al. (2012) found that the highest grain yield was achieved with Sakha 94 and Gemmiza 9. Harb et al. (2012) revealed that Gemmiza 9 cultivar significantly exceeded Sakha 93 cultivar in grain yield fed-1. Atia and Ragab (2013) found that wheat cultivars significantly differed in grain and straw yields as well as protein and potassium contents in grains. Gemmiza 9 cultivar had the greatest values of grain and straw yields as well as protein and potassium contents in grains. Seleem and Abd El Dayem (2013) showed that the highest significant value of grain yield was obtained using Gemmiza 9 followed by Misr 1 then Sakha 94 and Giza 168. The lowest values resulted from Sakha 93 cultivar.

The continued use of chemical fertilizers causes health and environmental hazards. Reducing the amount of nitrogen fertilizers applied to the field without nitrogen deficiency will be the main challenge in field management. One of the possible options to reduce the use of chemical fertilizers could be recycling of organic wastes. Compost can be a valuable and inexpensive fertilizer and source of plant nutrients. Positive effects of compost on soil structure, aggregate stability and water-holding capacity were reported (Odlare et al., 2008).

Compost has a high nutritional value, with high concentrations of especially nitrogen, phosphorus and potassium, while the contamination with heavy metals and other toxic substances is very limited. (Asghar et al., 2006). In order to improve nitrogen application management, many studies showed that the combination of compost with chemical fertilizers further enhanced the biomass and grain yield of crops (Cheuk et al., 2003; Sarwar et al., 2007; Sarwar et al., 2008). Mahmoud et al. (2006) found that grain and straw yields of wheat and $\mathrm{N}, \mathrm{P}$ and $\mathrm{K}$ uptake in grains and straw as well as crude protein content were increased by the application of $75 \%$ of $\mathrm{N}$ as ammonium sulfate with $25 \%$ composting rice straw. Abedi et al. (2010) evaluated the effects of different levels of inorganic $(0,80,160$ and $\left.240 \mathrm{~kg} \mathrm{~N} \mathrm{ha}{ }^{-1}\right)$ and organic $\left(0,30\right.$ and $60 \mathrm{Mg} \mathrm{ha}^{-1}$ municipal waste compost ha ${ }^{-1}$ ) on wheat grain yield and protein content. They reported that the highest wheat grain yield was achieved when plants were fertilized with $160 \mathrm{~kg} \mathrm{~N} \mathrm{ha}^{-1}$ and $30 \mathrm{Mg}$ compost ha $^{-1}$. The highest amount of seed protein was obtained with $60 \mathrm{Mg}$ compost $\mathrm{ha}^{-1}$ at all levels of nitrogen. Antoun, Linda et al. (2010) found that the interaction between compost and inorganic nitrogen level had significant effects on grain yield fed $^{-1}$ and $\mathrm{N}, \mathrm{P}$ and $\mathrm{K} \%$ in grains. El-Hamdi et al. (2012) reported that the combination of compost and nitrogen fertilizer improved yields, yield components and $\mathrm{N}$ uptake. The best treatment was $50 \mathrm{~kg}$ $\mathrm{N}$ fed $^{-1}$ with adding $10 \mathrm{Mg}$ compost fed $^{-1}$.

The present, investigation was established to study the effect of mineral nitrogen and compost combination treatments on yield and $\mathrm{N}, \mathrm{P}$ and $\mathrm{K}$ uptake in grain and straw for some wheat cultivars under the 
environmental conditions of El-Serw district, Damietta Governorate.

\section{MATERIALS AND METHODS}

Two field experiments were conducted at the Experimental Research Station at El-Serw, Agricultural Research Center,Egypt during the two successive winter seasons of 2012/2013 and 2013/2014. experiments was carried out in a split plot design with three replicates. The main plots were assigned to three wheat cultivars i.e., Sakha 93, Gemmiza 9 and Gemmiza 10. While the sub main plots were devoted to five nitrogen and compost combination treatments as follows:

1- $100 \%$ inorganic nitrogen $\left(90 \mathrm{~kg} \mathrm{~N} \mathrm{fed}^{-1}\right)$ of the recommended dose of $\mathrm{N}$.

2- $75 \%$ inorganic nitrogen $\left(67.5 \mathrm{~kg} \mathrm{~N} \mathrm{fed}^{-1}\right)+25 \%$ organic nitrogen $\left(22.5 \mathrm{~kg} \mathrm{~N}\right.$ fed $\left.{ }^{-1}\right)$.

3- $50 \%$ inorganic nitrogen $\left(45.0 \mathrm{~kg} \mathrm{~N} \mathrm{fed}^{-1}\right)+50 \%$ organic nitrogen $\left(45.0 \mathrm{~kg} \mathrm{~N} \mathrm{fed}^{-1}\right)$.
4- $25 \%$ inorganic nitrogen $\left(22.5 \mathrm{~kg} \mathrm{~N} \mathrm{fed}^{-1}\right)+75 \%$ organic nitrogen $\left(67.5 \mathrm{~kg} \mathrm{~N} \mathrm{fed}^{-1}\right)$.

$5-100 \%$ organic nitrogen $\left(90 \mathrm{~kg} \mathrm{~N}\right.$ fed $\left.^{-1}\right)$

The organic nitrogen in the form of compost was obtained from El-Asria Company for Solid Waste Recycling and added after soil preparation to the experimental units at the previously mentioned rates on soil surface and then turned over via hack. Analysis of used compost is shown in Table (1). Nitrogen fertilizer in the form of ammonium nitrate $(33.5 \% \mathrm{~N})$ was applied at the aforementioned rates in two equal doses prior the first (25 days from sowing) and the second (46 days from sowing) irrigations. Each experimental unit was $3 \times 3.5 \mathrm{~m}$ occupying an area of $10.5 \mathrm{~m}^{2}$. The amount of compost needed was calculated as follows:

Amount of Compost $=\frac{\text { Amount of mineral Nitrogen }}{\text { Nitrogen percentage in Compost }} \times 100$

Harvest index ( $\mathrm{HI}$ ) was determined using the formula :

HI = Grain yield (kglfed.) $\backslash$ Grain yield (kglfed.)+ Straw yield (kglfed.) $\times 100$

Table (1) : Chemical composition of used compost

\begin{tabular}{lcccccccccc}
\hline Parameters EC (dSm-1) & pH (1-2.5) & T.N\% & T..C.\% & T.P.\% & T.K.\% & C:N & Fe & Mn & Zn & Cu \\
\hline Value & 3.1 & 7.7 & 1.4 & 22.1 & 0.7 & 1.0 & $16: 1$ & \multirow{2}{*}{$\begin{array}{c}\left(\mathbf{p p m L}^{-1}\right) \\
35\end{array}$} & 180 & 105 \\
\hline
\end{tabular}

* $\mathbf{T}=$ Total

Soil samples were taken from the experimental field before and after harvest from soil layer $(0-30 \mathrm{~cm}$ depth), then air-dried and ground to pass a $2 \mathrm{~mm}$ sieve. Soil physical and chemical properties were carried out

according to Piper (1950) and Jackson (1967) as shown in Table (2). EC, cations and anions were estimated in 1:5 soil water extract, where $\mathrm{pH}$ was measured in soil water suspensions (1:2.5) as shown in Table 2.

Table(2):Some Physical and chemical properties of the experimental sites .

\begin{tabular}{|c|c|c|c|c|c|c|c|c|}
\hline \multicolumn{6}{|c|}{ Particle size distribution \% } & \multirow{2}{*}{$\begin{array}{c}\text { O.M } \\
\%\end{array}$} & \multirow{2}{*}{$\begin{array}{c}\mathrm{CaCO}_{3} \\
\%\end{array}$} & \multirow{2}{*}{$\begin{array}{c}\text { CEC } \\
\text { Mel.l100 g soil }\end{array}$} \\
\hline C. sand & & F. sand & Silt & Clay & T.class & & & \\
\hline 1.10 & & 11.2 & 21.7 & 66.0 & Clay & 0.77 & 1.40 & 43.8 \\
\hline $\mathrm{EC}$ & $\mathrm{pH}$ & \multicolumn{4}{|c|}{ Cations (meq $\backslash 100 \mathrm{~g})$} & \multicolumn{3}{|c|}{ Anions (meq $\backslash 100 \mathrm{~g}$ ) } \\
\hline$(\mathrm{dsm}-1)$ & $(1-2.5)$ & $\mathrm{Ca}++$ & $\mathrm{Mg}++$ & $\mathrm{Na}+$ & $\mathrm{K}+$ & $\mathrm{HCO}_{3}$ & $\mathrm{Cl}$ & $\mathrm{SO}_{4}$ \\
\hline 2.35 & 8.1 & 3.05 & 2.76 & 11.3 & 0.26 & 1.45 & 12.1 & 3.75 \\
\hline
\end{tabular}

Calcium superphosphate fertilizer $\left(15.5 \% \quad \mathrm{P}_{2} \mathrm{O}_{5}\right)$ was added at a rate of $100 \mathrm{Kg} \mathrm{fed}^{-1}$ as basal of each plot before tillage.

Sowing took place on November 18th and 25th in the first and second seasons, respectively. Wheat harvesting was done on 20th April 2012 and 1st May 2013 in both seasons, respectively. The first irrigation was applied at 25 days after sowing and then plants were irrigated every 21 days till the dough stage. The common agricultural practices for growing wheat according to the recommendations of Ministry of Agriculture were followed, except the factors under study.

After wheat harvest, grain and straw yields and $\mathrm{N}, \mathrm{P}$ and $\mathrm{K}$ uptake, Nutrient uptake was calculated as follows:

Nutrient element uptake $\mathrm{kg} \mathrm{fed}^{-1}=$ Nutrient element $\%+$ Yield $\left(\mathrm{kg} \mathrm{fed}^{-1}\right) \backslash 100$

Protein yield $\left(\mathrm{kg} \mathrm{fed}^{-1}\right.$.) in the grins was calculated by multiplying $\mathrm{N}-$ uptake $\left(\mathrm{kg} \mathrm{fed}^{-1}\right.$.) by 5.75 factor
Statistical analysis was carried out according to Steel and Torrie (1980) to compare the treatments values.

\section{RESULTS AND DISCUSSION}

\section{Grain and straw yield}

Data presented Table (3) showed that wheat varieties were significantly differed in their by grain and straw yield in both 1 st and 2 nd seasons, Gimmeza 10 variety had the greatest mean value of grain and straw yields followed by, Gimmeza 9, and Sakha 93. Also, data showed that yields were significantly affected by nitrogen combination treatments in both $1^{\text {st }}$ and $2^{\text {nd }}$ seasons and the order of nitrogen combination treatments were as follows: A $(100 \% \mathrm{MN}),>\mathrm{B}(75 \%$ $\mathrm{MN}+25 \%$ ON. $)>\mathrm{C}(50 \% \mathrm{MN}+50 \%$ ON. $)>\mathrm{D}(25 \%$ $\mathrm{MN}+75 \%$ ON. $)>\mathrm{E}(100 \%$ ON. $)$. El-Metwally et al. (2012) found that Sakha 94 and Gimmeza 9 respectively gave the highest grain yield. 
Data also showed that the interaction between cultivars and nitrogen combination treatments had a significant effect on grain and straw yield in both $1^{\text {st }}$ and $2^{\text {nd }}$ seasons. Data presented in Table 3 showed that, the highest values of grain yield (2.651 and $2.732 \mathrm{Mg} \mathrm{fed}^{-1}$ ) and straw yield (3.557 and $\left.3.681 \mathrm{Mg} \mathrm{fed}^{-1}\right)$ were obtained when Gemmiza 10 cultivar revived $(A=100 \%$ MN) $90 \mathrm{~kg} \mathrm{~N} \mathrm{fed}^{-1}$ in the first and second seasons, respectively. Also, data in Table 3 showed that no significant effect between A (100 MN) and B (100\%
$\mathrm{MN}+25 \% \mathrm{ON}$.) for both grain and straw yield at $2012 / 2013$ season and grain yield for 2013/2014 season for Sakha 93 variety only. So, it may be saved $25 \%$ inorganic nitrogen when applying it as compost. The previous results may be refer to the combination of compost with inorganic nitrogen fertilization further enhanced the biomass, therefore increasing in wheat yield. The similar results were obtained with (Mahmoud et al., 2006 and Abedi, et al., 2010).

Table (3): Grain and straw yield $\left(\mathrm{Mg}^{\mathrm{fed}}{ }^{-1}\right)$ as affected by varieties and nitrogen and compost combination applications during the seasons 2012/2013 and 2013/2014.

\begin{tabular}{|c|c|c|c|c|c|}
\hline \multicolumn{2}{|c|}{ Treatment } & \multicolumn{2}{|c|}{$2012 / 2013$} & \multicolumn{2}{|c|}{$2013 / 2014$} \\
\hline Varieties & $\begin{array}{c}\text { Minr.* } \\
\text { Org. }\end{array}$ & $\begin{array}{c}\text { Grain } \\
\text { Yield }\end{array}$ & $\begin{array}{c}\text { Straw } \\
\text { Yield }\end{array}$ & $\begin{array}{c}\text { Grain } \\
\text { Yield }\end{array}$ & $\begin{array}{c}\text { Straw } \\
\text { Yield }\end{array}$ \\
\hline \multirow{5}{*}{ Sakha 93} & $\mathrm{~A}$ & 2.50 & 3.35 & 2.53 & 3.38 \\
\hline & B & 2.46 & 3.32 & 2.51 & 3.40 \\
\hline & $\mathrm{C}$ & 2.35 & 3.21 & 2.44 & 3.35 \\
\hline & $\mathrm{D}$ & 1.93 & 2.83 & 2.00 & 2.95 \\
\hline & $\mathrm{E}$ & 1.75 & 2.52 & 1.82 & 2.64 \\
\hline \multirow{5}{*}{ Gemmiza 9} & A & 2.59 & 3.43 & 2.66 & 3.54 \\
\hline & B & 2.48 & 3.34 & 2.56 & 3.46 \\
\hline & $\mathrm{C}$ & 2.40 & 3.33 & 2.49 & 3.46 \\
\hline & $\mathrm{D}$ & 1.94 & 2.88 & 2.13 & 3.17 \\
\hline & $\mathrm{E}$ & 1.76 & 2.60 & 1.84 & 2.73 \\
\hline \multirow{5}{*}{ Gemmiza 10} & A & 2.65 & 3.56 & 2.73 & 3.68 \\
\hline & $\mathrm{B}$ & 2.56 & 3.43 & 2.67 & 3.59 \\
\hline & $\mathrm{C}$ & 2.39 & 3.20 & 2.51 & 3.37 \\
\hline & $\mathrm{D}$ & 2.04 & 2.92 & 2.21 & 3.18 \\
\hline & $\mathrm{E}$ & 1.77 & 2.61 & 1.86 & 2.75 \\
\hline $\mathrm{F}$ & & $* *$ & $* *$ & $* *$ & $* *$ \\
\hline LSD $5 \%$ & & 0.039 & 0.049 & 0.030 & 0.018 \\
\hline LSD $1 \%$ & & 0.054 & 0.062 & 0.047 & 0.024 \\
\hline \multirow{2}{*}{ F } & Varieties & $* *$ & $* *$ & $* *$ & $* *$ \\
\hline & Minr.*Org. & $* *$ & $* *$ & $* *$ & $* *$ \\
\hline
\end{tabular}

*Significant at $5 \%$ level. $* *$ Significant at $1 \%$ level.

$A=100 \% M N B=75 \% M N+25 \%$ ON.C $=50 \% \mathrm{MN}+50 \%$ ON. $D=25 \% \mathrm{MN}+75 \%$ ON. $\mathrm{E}=100 \% \mathrm{ON}$.

$\mathrm{MN}=$ Inorganic nitrogen ON. = Organic Nitrogen as Compost.

Nitrogen uptake in wheat grain and straw $\left(\mathrm{kg} \mathrm{N} \mathrm{fed}^{-1}\right)$. Data presented Table (4) show that nitrogen uptake was significantly affected in both wheat grain and straw (total nitrogen removed by the crop from the soil in grain and straw) in both seasons by wheat verities. Gimmeza 10 variety had the greatest mean value of $\mathrm{N}$ uptake in both grain and straw followed by, Gimmeza 9, and Sakha 93. There was significant increase in $\mathrm{N}$ uptake in wheat grain and straw in both seasons, by nitrogen combination treatments, the highest mean values of $\mathrm{N}$ uptake in grains and straw in 2012/2013 and 2013/2014 seasons were recorded with $\mathrm{A}(100 \% \mathrm{MN}), \mathrm{B}(75 \% \mathrm{MN}+25 \% \mathrm{ON}$.), C (50\% MN $+50 \%$ ON.), D (25\% MN $+75 \%$ ON.) and $\mathrm{E}(100 \%$
ON.), respectively. Also, data Table (4) showed that the interaction between cultivars and nitrogen combination treatments was significant on $\mathrm{N}$ uptake in both wheat grain and straw in both seasons. The greatest values of $\mathrm{N}$ uptake for wheat grains and straw in both seasons, were obtained with Gemmiza 10 variety and Gemmiza 9 respectively when using teratments $(A=100 \% \mathrm{MN}) 90$ $\mathrm{kg} \mathrm{N}$ fed $^{-1}$. These increases in $\mathrm{N}$ uptake values in grain and straw yield could be due to compost fertilization that has a high nutritional value, with high concentrations of especially nitrogen and to improving physical and chemical soil properties. These results agree with those obtained by (Mahmoud et al., 2006 and El-Hamdi et al., 2012). 
Khafagy, E.E.E.

Table (4): Nitrogen uptake $\left(\mathrm{kg} \mathrm{N} \mathrm{fed}^{-1}\right)$ in grain and straw as affected by varieties and nitrogen and compost combination applications during the seasons 2012/2013 and 2013/2014.

\begin{tabular}{|c|c|c|c|c|c|}
\hline \multicolumn{2}{|c|}{ Treatment } & \multicolumn{2}{|c|}{$2012 / 2013$} & \multicolumn{2}{|c|}{$2013 / 2014$} \\
\hline Varieties & Minr.*Org. & Grain & Straw & Grain & Straw \\
\hline \multirow{5}{*}{$\begin{array}{l}\text { Sakha } \\
93\end{array}$} & A & 37.22 & 6.72 & 37.66 & 6.83 \\
\hline & B & 34.44 & 5.71 & 35.63 & 5.95 \\
\hline & $\mathrm{C}$ & 31.68 & 4.79 & 32.94 & 5.09 \\
\hline & D & 23.99 & 3.93 & 24.95 & 4.17 \\
\hline & E & 20.09 & 3.42 & 21.02 & 3.62 \\
\hline \multirow{5}{*}{ Gemmiza 9} & A & 38.61 & 7.00 & 39.70 & 7.26 \\
\hline & B & 35.78 & 5.84 & 36.94 & 6.22 \\
\hline & $\mathrm{C}$ & 32.48 & 5.15 & 33.78 & 5.40 \\
\hline & D & 24.17 & 4.07 & 26.54 & 4.60 \\
\hline & $\mathrm{E}$ & 20.40 & 3.56 & 21.31 & 3.80 \\
\hline \multirow{5}{*}{ Gemmiza 10} & A & 39.85 & 7.40 & 41.25 & 7.69 \\
\hline & B & 37.18 & 6.48 & 38.82 & 6.86 \\
\hline & $\mathrm{C}$ & 32.36 & 5.35 & 34.11 & 5.67 \\
\hline & D & 25.91 & 4.23 & 28.13 & 4.76 \\
\hline & $\mathrm{E}$ & 21.44 & 3.63 & 22.51 & 3.85 \\
\hline $\mathrm{F}$ & & $* *$ & $* *$ & ** & $* *$ \\
\hline LSD 5\% & & 0.497 & 0.164 & 0.395 & 0.146 \\
\hline LSD $1 \%$ & & 0.553 & 0.224 & 0.451 & 0.247 \\
\hline \multirow{2}{*}{$\mathrm{F}$} & Varieties & $* *$ & $* *$ & $* *$ & $* *$ \\
\hline & Minr.*Org. & $* *$ & ** & ** & ** \\
\hline
\end{tabular}

*Significant at $5 \%$ level. $* *$ Significant at $1 \%$ level.

$A=100 \% M N B=75 \% M N+25 \%$ ON. C=50\%MN + 50\% ON. D= 25\%MN + 75\% ON. E $=100 \%$ ON.

$\mathrm{MN}=$ Inorganic nitrogen ON. = Organic Nitrogen as Compost.

\section{Phosphorus uptake in wheat grains and straw $\left(k \mathrm{P}\right.$ fed $\left.^{-1}\right)$.}

Data in Table (5) show significant increase in phosphor uptake in both wheat grain and straw (total phosphor removed by the crop from the soil in grain and straw) in both seasons by wheat verities. Also, as in previous variables, Gimmeza 10 variety had the greastest mean value of $\mathrm{P}$ uptake in both grain and straw followed by, Gimmeza 9, and Sakha 93. Also, there was significant increment in $\mathrm{P}$ uptake in wheat grain and straw in both seasons, by nitrogen combination treatments, the greatest mean values of $\mathrm{P}$ uptake in grains and straw in 2012/2013 and 2013/2014 seasons were recorded with $\mathrm{A}(100 \% \mathrm{MN}), \mathrm{B}(75 \% \mathrm{MN}+25 \%$ ON.), C (50\% MN + 50\% ON.), D (25\% MN + 75\% ON.) and E (100\% ON.), respectively. Data also Table (5) show that the interaction between cultivars and nitrogen combination treatments was significant on $\mathrm{P}$ uptake in wheat grain in 2012/2013 season and in wheat straw in 2013/2014 seasons and but effect was observed no significant on $p$ uptake in wheat grain in 2012/2013 seasons and in wheat straw in 2013/2014 season. The greatest values of $\mathrm{P}$ uptake for wheat grains and straw in both seasons, were obtained with variety of Gemmiza 10 and Gemmiza 9 respectively when grown with $(\mathrm{A}=100 \% \mathrm{MN}) 90 \mathrm{~kg} \mathrm{~N}$ fed-1. Mahmoud et al., 2006 was found similar results for this variance.
Potassium uptake in wheat grain and straw $\left(\mathrm{kg} \mathrm{K} \mathrm{fed}^{-1}\right)$.

Data presented Table (6) show that potassium uptake(total potassium removed by the crop from the soil in grain and straw) significantly increase in both wheat grain and straw in both seasons by wheat verities. The greatest mean value of $\mathrm{K}$ uptake in both grain and straw were obtained with Gimmeza 10 variety followed by, Gimmeza 9, and Sakha 93. There was significant increment in $\mathrm{K}$ uptake in wheat grain and straw in both 2012/2013 and 2013/2014 seasons, by nitrogen combination treatments, the highest mean values of $\mathrm{N}$ uptake in grains and straw in 2012/2013 and $2013 / 2014$ seasons were recorded with A $(100 \% \mathrm{MN})$, $\mathrm{B}(75 \% \mathrm{MN}+25 \% \mathrm{ON}$.), C (50\% MN + 50\% ON.), D $(25 \% \mathrm{MN}+75 \%$ ON.) and $\mathrm{E}(100 \%$ ON.), respectively. Data Table (6) show that interaction effect between cultivars and nitrogen combination treatments was significant on K uptake in wheat grain in 2011/2012 season and in straw in 2012/2013 season. Data also showed that the previous interaction was significant at $5 \%$ on $\mathrm{K}$ uptake in wheat grain in 2013/2014 season, and it was not significant in wheat straw in 2012/2013 season. The greatest values of $\mathrm{K}$ uptake for wheat grains and straw in both seasons, were obtained with variety Gemmiza 10 and Gemmiza 9 respectively when grown with $(\mathrm{A}=100 \% \mathrm{MN}) 90 \mathrm{~kg} \mathrm{~N}$ fed-1. These results are in line with those obtained by Mahmoud et al., (2006) ; Antoun, and Linda et al., (2010). 
Table (5): Phosphorus uptake $\left(\mathrm{kg} \mathrm{P} \mathrm{fed}{ }^{-1}\right)$ in grain and straw as affected by the interaction between varieties and nitrogen and compost combination treatments during 2012/2013 and 2013/2014 seasons.

\begin{tabular}{|c|c|c|c|c|c|}
\hline \multicolumn{2}{|c|}{ Treatment } & \multicolumn{2}{|c|}{$2012 / 2013$} & \multicolumn{2}{|c|}{$2013 / 2014$} \\
\hline Varieties & Minr.*Org. & Grain & Straw & Grain & Straw \\
\hline \multirow{4}{*}{ Sakha 93} & $\mathrm{~A}$ & 6.52 & 3.88 & 6.57 & 3.89 \\
\hline & B & 5.79 & 3.72 & 5.93 & 3.81 \\
\hline & $\mathrm{C}$ & 5.19 & 3.28 & 5.48 & 3.45 \\
\hline & $\mathrm{D}$ & 3.45 & 2.52 & 3.60 & 2.57 \\
\hline \multirow{6}{*}{ Gemmiza 9} & $\mathrm{E}$ & 2.08 & 2.14 & 2.19 & 2.27 \\
\hline & A & 6.78 & 3.98 & 6.99 & 4.11 \\
\hline & B & 5.98 & 3.77 & 6.22 & 3.94 \\
\hline & $\mathrm{C}$ & 5.50 & 3.46 & 5.75 & 3.60 \\
\hline & $\mathrm{D}$ & 3.61 & 2.65 & 3.93 & 2.95 \\
\hline & $\mathrm{E}$ & 2.26 & 2.23 & 2.30 & 2.38 \\
\hline \multirow{5}{*}{ Gemmiza 10} & A & 7.13 & 4.20 & 7.38 & 4.38 \\
\hline & B & 6.30 & 3.91 & 6.54 & 4.13 \\
\hline & $\mathrm{C}$ & 5.59 & 3.36 & 5.99 & 3.54 \\
\hline & $\mathrm{D}$ & 4.06 & 2.86 & 4.36 & 3.14 \\
\hline & $\mathrm{E}$ & 2.36 & 2.32 & 2.49 & 2.50 \\
\hline $\mathrm{F}$ & & $* *$ & Ns & Ns & $* *$ \\
\hline LSD $5 \%$ & & 0.064 & 1.896 & 0.251 & 0.119 \\
\hline LSD $1 \%$ & & 0.079 & 2.012 & 0.344 & 0.167 \\
\hline \multirow{2}{*}{ F } & Varieties & $* *$ & $\mathrm{Ns}$ & $* *$ & $* *$ \\
\hline & Minr.*Org. & $* *$ & $*$ & $* *$ & $* *$ \\
\hline
\end{tabular}

*Significant at $5 \%$ level. $\quad * *$ Significant at $1 \%$ level.

$A=100 \% M N B=75 \% M N+25 \%$ ON. C $=50 \% \mathrm{MN}+50 \%$ ON. $D=25 \% \mathrm{MN}+75 \%$ ON. E $=100 \% \mathrm{ON}$.

$\mathrm{MN}=$ Inorganic nitrogen ON. = Organic Nitrogen as Compost.

Table (6): Potassium uptake (kg fed ${ }^{-1}$ ) in grain and straw as affected by the interaction between varieties and nitrogen and compost combination treatments during 2012/2013 and 2013/2014 seasons.

\begin{tabular}{|c|c|c|c|c|c|}
\hline \multicolumn{2}{|c|}{ Treatment } & \multicolumn{2}{|c|}{$2012 / 2013$} & \multicolumn{2}{|c|}{$2013 / 2014$} \\
\hline Varieties & Minr.*Org. & Grain & Straw & Grain & Straw \\
\hline \multirow{5}{*}{ Sakha 93} & $\mathrm{~A}$ & 0.58 & 29.77 & 0.61 & 30.27 \\
\hline & B & 0.44 & 28.27 & 0.50 & 28.92 \\
\hline & $\mathrm{C}$ & 0.35 & 26.18 & 0.41 & 27.34 \\
\hline & $\mathrm{D}$ & 0.21 & 22.11 & 0.24 & 23.16 \\
\hline & $\mathrm{E}$ & 0.12 & 18.84 & 0.16 & 19.89 \\
\hline \multirow{5}{*}{ Gemmiza 9} & A & 0.62 & 31.21 & 0.64 & 32.52 \\
\hline & B & 0.55 & 28.94 & 0.59 & 30.10 \\
\hline & $\mathrm{C}$ & 0.41 & 27.37 & 0.45 & 28.58 \\
\hline & $\mathrm{D}$ & 0.25 & 22.75 & 0.30 & 25.08 \\
\hline & $\mathrm{E}$ & 0.16 & 19.98 & 0.20 & 21.10 \\
\hline \multirow{5}{*}{ Gemmiza 10} & A & 0.69 & 32.72 & 0.74 & 33.98 \\
\hline & B & 0.64 & 30.70 & 0.67 & 32.18 \\
\hline & $\mathrm{C}$ & 0.43 & 27.28 & 0.45 & 28.88 \\
\hline & $\mathrm{D}$ & 0.29 & 23.72 & 0.33 & 26.04 \\
\hline & $\mathrm{E}$ & 0.21 & 20.49 & 0.22 & 21.75 \\
\hline $\mathrm{F}$ & & $* *$ & Ns & $*$ & $* *$ \\
\hline LSD $5 \%$ & & 0.020 & 1.551 & 0.050 & 0.193 \\
\hline LSD $1 \%$ & & 0.037 & 1.899 & 0.071 & 0.234 \\
\hline \multirow{2}{*}{ F } & Varieties & $* *$ & $*$ & $* *$ & $* *$ \\
\hline & Minr.*Org. & $* *$ & $* *$ & $* *$ & $* *$ \\
\hline
\end{tabular}

*Significant at $5 \%$ level. $* *$ Significant at $1 \%$ level.

$A=100 \% M N B=75 \% M N+25 \%$ ON.C $=50 \% M N+50 \%$ ON. $D=25 \% M N+75 \%$ ON. $E=100 \%$ ON.

$\mathrm{MN}=$ Inorganic nitrogen ON. = Organic Nitrogen as Compost.

Protein Yield $\left(\mathrm{Kgfed}^{-1}\right.$.) :

Results presented in Table ( 7 ) show that protein yield (Kgfed-1.) in wheat grains in all wheat varieties was increased by increasing $\mathrm{N}$. fertilization levels up to $90 \mathrm{Kg} \mathrm{N}$. fed-1. It was noticed that the maximum value of protein yield was $229 \mathrm{Kgfed}-1$. A relative increase of
$86 \%$,were attained by the addition of $100 \%$ inorganic nitrogen ( $90 \mathrm{Kg}$ N.fed-1.), while the lowest one (115.5 Kgfed-1), was obtained in Sakha 93 variety by applying $100 \%$ organic nitrogen. The protein yield (Kgfed-1.) for wheat varieties can be arranged descendingly as fallow: 
Khafagy, E.E.E.

G10 > G9 > Sakha 93, while the protein yield

(Kgfed-1. for all treatments can be arranged

trend was observed in the second season either with descendingly as fallow: $\mathrm{A}>\mathrm{B}>\mathrm{C}>\mathrm{D}>\mathrm{E}$. The same

wheat variety or with other treatments.

Table(7): Effect of the interaction between varieties and nitrogen and compost combination treatments on Protein Yield during 2012/2013 and 2013/2014 seasons.

\begin{tabular}{|c|c|c|c|}
\hline \multicolumn{2}{|c|}{ Treatment } & \multirow{2}{*}{$\begin{array}{c}2012 / 2013 \\
\text { Protein Yield }\end{array}$} & \multirow{2}{*}{$\begin{array}{c}2013 / 2014 \\
\text { Protein Yield }\end{array}$} \\
\hline Varieties & Minr.*Org. & & \\
\hline \multirow{5}{*}{ Sakha 93} & $\mathrm{~A}$ & 214.0 & 216.5 \\
\hline & B & 198.0 & 204.8 \\
\hline & $\mathrm{C}$ & 183.3 & 189.3 \\
\hline & D & 137.9 & 143.5 \\
\hline & $\mathrm{E}$ & 115.5 & 121.3 \\
\hline \multirow{5}{*}{ Gemmiza 9} & A & 222.0 & 228.2 \\
\hline & B & 205.7 & 212.3 \\
\hline & $\mathrm{C}$ & 186.7 & 194.2 \\
\hline & $\mathrm{D}$ & 138.9 & 152.5 \\
\hline & $\mathrm{E}$ & 117.2 & 122.5 \\
\hline \multirow{5}{*}{ Gemmiza 10} & A & 229.1 & 237.2 \\
\hline & B & 213.8 & 223.2 \\
\hline & $\mathrm{C}$ & 186.0 & 196.1 \\
\hline & $\mathrm{D}$ & 149.0 & 161.7 \\
\hline & $\mathrm{E}$ & 123.2 & 129.4 \\
\hline $\mathrm{F}$ & & $* *$ & Ns \\
\hline LSD $5 \%$ & & 0.064 & 0.251 \\
\hline LSD $1 \%$ & & 0.079 & 0.344 \\
\hline \multirow{2}{*}{$\mathrm{F}$} & Varieties & $* *$ & $* *$ \\
\hline & Minr.*Org. & $* *$ & $* *$ \\
\hline
\end{tabular}

*Significant at $5 \%$ level. $* *$ Significant at $1 \%$ level.

$A=100 \% M N$ B $=75 \% \mathrm{MN}+25 \%$ ON. C $=50 \% \mathrm{MN}+50 \% \mathrm{ON} . \mathrm{D}=\mathbf{2 5} \% \mathrm{MN}+75 \% \mathrm{ON} . \mathrm{E}=100 \% \mathrm{ON}$.

$\mathrm{MN}=$ Inorganic nitrogen ON. = Organic Nitrogen as Compost.

\section{GlS ratio (Grain $\backslash$ Straw percentage)}

Data presented in Table (8) indicate significant differences in grain $\backslash$ straw percentage among the studied wheat varieties and different treatments. The GIS ratio was influenced by the interaction between mineral nitrogen and organic $\mathrm{N}$ and wheat varieties. The GIS ratio decreased by increasing the application rate of organic nitrogen, where Gammiza 10 variety surpassed all other varieties. The same trend was observed in treatments where a treatment surpassed all other treatments. GIS ratio can be arranged descending as follows: A > B > C > D > E. The same trend was observed in the second season either with wheat variety or with treatments.

Table (8): Effect of the interaction between varieties and nitrogen and compost combination treatments on Crop index (GIS ratio )during the seasons 2012/2013 and 2013/2014.

\begin{tabular}{|c|c|c|c|}
\hline \multicolumn{2}{|c|}{ Treatment } & \multirow{2}{*}{$\begin{array}{c}2012 / 2013 \\
\text { Crop index }\end{array}$} & \multirow{2}{*}{$\begin{array}{c}2013 / 2014 \\
\text { Crop index }\end{array}$} \\
\hline Varieties & Minr.*Org. & & \\
\hline \multirow{5}{*}{ Sakha 93} & $\mathrm{~A}$ & 0.75 & 0.74 \\
\hline & B & 0.74 & 0.64 \\
\hline & $\mathrm{C}$ & 0.73 & 0.73 \\
\hline & $\mathrm{D}$ & 0.67 & 0.68 \\
\hline & $\mathrm{E}$ & 0.68 & 0.69 \\
\hline \multirow{5}{*}{ Gemmiza 9} & $\mathrm{~A}$ & 0.75 & 0.75 \\
\hline & B & 0.75 & 0.74 \\
\hline & $\mathrm{C}$ & 0.73 & 0.72 \\
\hline & $\mathrm{D}$ & 0.67 & 0.67 \\
\hline & $\mathrm{E}$ & 0.68 & 0.67 \\
\hline \multirow{5}{*}{ Gemmiza 10} & A & 0.75 & 0.74 \\
\hline & B & 0.75 & 0.74 \\
\hline & $\mathrm{C}$ & 0.74 & 0.74 \\
\hline & $\mathrm{D}$ & 0.67 & 0.70 \\
\hline & $\mathrm{E}$ & 0.68 & 0.68 \\
\hline $\mathrm{F}$ & & $* *$ & $\mathrm{Ns}$ \\
\hline LSD 5\% & & 0.064 & 0.251 \\
\hline LSD $1 \%$ & & 0.079 & 0.344 \\
\hline \multirow{2}{*}{$\mathrm{F}$} & Varieties & $* *$ & $* *$ \\
\hline & Minr.*Org. & $* *$ & $* *$ \\
\hline
\end{tabular}

*Significant at $5 \%$ level. $* *$ Significant at $1 \%$ level.

$A=100 \% M N \quad B=75 \% M N+25 \%$ ON. $C=50 \% M N+50 \%$ ON. $D=25 \% M N+75 \%$ ON. E $=100 \%$ ON.

$\mathrm{MN}=$ Inorganic nitrogen ON. = Organic Nitrogen as Compost. 


\section{Harvest index:}

Harvest index of wheat production as affected by the studied treatments is shown in Table (9). The lower mean values were noticed for the sakha 93 variety, while the highest mean values were obtained for Gammiza 10 variety. Results also indicated that the addition of $100 \%$ inorganic nitrogen gave the maximum value where the relative increase reaches $8.17 \%$ in comparison with $\mathrm{E}$ treatment. The relative increase for all treatments can be arranged descending as fallow: A $>\mathrm{B}>\mathrm{C}>\mathrm{D}>\mathrm{E}$. The same trend was observed in the second season either with wheat variety or with treatments.

Table(9): Effect of the interaction between varieties and nitrogen and compost combination treatments on harvest index during 2012/2013 and 2013/2014 seasons.

\begin{tabular}{|c|c|c|c|c|c|}
\hline \multirow[b]{2}{*}{ Varieties } & Treatment & \multicolumn{2}{|c|}{$2012 / 2013$} & \multicolumn{2}{|c|}{$2013 / 2014$} \\
\hline & $\begin{array}{c}\text { Minr.* } \\
\text { Org. }\end{array}$ & $\begin{array}{c}\text { Harvest } \\
\text { index }\end{array}$ & $\begin{array}{c}\text { Relative } \\
\text { increase }(\%)\end{array}$ & $\begin{array}{c}\text { Harvest } \\
\text { index }\end{array}$ & $\begin{array}{c}\text { Relative } \\
\text { increase }(\%)\end{array}$ \\
\hline \multirow{5}{*}{ Sakha 93} & $\mathrm{~A}$ & 42.8 & 6.20 & 42.8 & 4.90 \\
\hline & B & 42.6 & 5.71 & 42.5 & 4.17 \\
\hline & $\mathrm{C}$ & 42.2 & 4.71 & 42.1 & 3.19 \\
\hline & $\mathrm{D}$ & 40.5 & 0.50 & 40.4 & 0.25 \\
\hline & $\mathrm{E}$ & 40.3 & ----- & 40.8 & ----- \\
\hline \multirow{5}{*}{ Gemmiza 9} & A & 43.0 & 6.43 & 42.9 & 6.72 \\
\hline & B & 42.7 & 5.69 & 42.5 & 5.72 \\
\hline & $\mathrm{C}$ & 41.9 & 3.71 & 41.8 & 3.98 \\
\hline & $\mathrm{D}$ & 41.5 & 2.72 & 40.1 & 2.99 \\
\hline & $\mathrm{E}$ & 40.4 & ----- & 40.2 & ------ \\
\hline \multirow{5}{*}{ Gemmiza 10} & A & 43.7 & 8.17 & 43.0 & 6.97 \\
\hline & B & 42.7 & 5.69 & 42.6 & 5.97 \\
\hline & $\mathrm{C}$ & 42.7 & 5.69 & 42.6 & 5.97 \\
\hline & $\mathrm{D}$ & 41.6 & 2.97 & 41.1 & 2.24 \\
\hline & $\mathrm{E}$ & 40.4 & ----- & 40.2 & ---- \\
\hline $\mathrm{F}$ & & $* *$ & Ns & Ns & $* *$ \\
\hline LSD $5 \%$ & & 0.064 & 1.896 & 0.251 & 0.119 \\
\hline LSD $1 \%$ & & 0.079 & 2.012 & 0.344 & 0.167 \\
\hline \multirow{2}{*}{ F } & Varieties & $* *$ & Ns & $* *$ & $* *$ \\
\hline & Minr.*Org. & $* *$ & $*$ & $* *$ & $* *$ \\
\hline
\end{tabular}

*Significant at 5\% level. $* *$ Significant at $1 \%$ level.

$A=100 \% M N \quad B=75 \% M N+25 \%$ ON. $C=50 \% M N+50 \%$ ON. $D=25 \% M N+75 \%$ ON. $E=100 \%$ ON.

$\mathrm{MN}=$ Inorganic nitrogen $\mathrm{ON} .=$ Organic Nitrogen as Compost.

Soil salinity $\left(\mathrm{EC}_{\mathrm{e}}\right)$ and $\mathrm{pH}$.

The movement of soluble salts in soil depends mainly on its texture, structure, total porosity and permeability. Data in Table (10) show the values of $\mathrm{EC}_{\mathrm{e}}$ and $\mathrm{pH}$ of the studied soil as influenced by treatments (A,B,C , D and E). Data indicated that the mean values of soil $\mathrm{EC}_{\mathrm{e}}$ and soil $\mathrm{pH}$ after harvesting for two seasons decreased with increasing organic fertilizer application.

Table (10): Soil pH, Electrical conductivity $\left(\mathrm{EC}_{\mathrm{e}}\right)$, Bulk density (B.D) and Hydraulic Conductivity (K) as affected by the studied after harvesting two seasons (combined analysis).

\begin{tabular}{|c|c|c|c|c|}
\hline Treatments & $\mathrm{EC}\left(\mathrm{dSm}^{-1}\right)$ & PH (1- 2.5) & B.D $\left(\mathrm{Mg} \mathrm{m}^{-1}\right)$ & $\mathrm{K}\left(\mathrm{cmh}^{-1}\right)$ \\
\hline$\overline{\mathrm{A}}$ & 2.41 & 8.1 & 1.41 & 0.85 \\
\hline B & 2.38 & 7.91 & 1.38 & 1.23 \\
\hline $\mathrm{C}$ & 2.35 & 7.86 & 1.34 & 1.28 \\
\hline D & 2.30 & 7.82 & 1.30 & 1.31 \\
\hline E & 2.25 & 7.80 & 1.28 & 1.33 \\
\hline
\end{tabular}

Soil bulk density.

It is well known that soil bulk density is mostly affected by soil structure. Mean values of soil bulk density $\left(\mathrm{Mgm}^{-3}\right)$ after wheat harvesting are presented in Table (10). Data revealed that increasing the applied rate of organic $\mathrm{N}$. treatments to the soil reduce of the values of soil bulk density, and consequently caused an increase in hydraulic conductivity. The efficiency of the studied treatments on reducing the values of bulk density could be arranged in the following ascending order: $\mathrm{E}>\mathrm{D}>\mathrm{C}>\mathrm{B}>\mathrm{A}$. These results may be attributed to the addition of organic matter which enhanced the formation of large soil aggregates. These results are in agreement with Mansour et.al. (2011).

\section{Hydraulic conductivity (HC).}

Data in Table (10) revealed that the values of soil hydraulic conductivity increased with the previous organic treatments (B, C, D and E), as compared with the A treatment. The hydraulic conductivity were increased from $0.85 \mathrm{~cm} \mathrm{~h}^{-1}$ in the A treatment to 1.33 $\mathrm{cm} \mathrm{h}^{-1}$ in $\mathrm{E}$ treatment, The treatments could be arranged in the following ascending order: $\mathrm{A}<\mathrm{B}<\mathrm{C}<\mathrm{D}<\mathrm{E}$ this may be attributed to the effect of organic treatments increasing the micro pores and decreasing the macro 


\section{Khafagy, E.E.E.}

pores. Similar results were obtained by Mansour (2007) and Mariano et al., (2009)

\section{CONCLUSION}

Based on the aforementioned discussion, It could be concluded that applying $75 \%$ inorganic nitrogen $\left(67.5 \mathrm{~kg} \mathrm{~N} \mathrm{fed}^{-1}\right)$ with $25 \%$ compost $\left(22.5 \mathrm{~kg} \mathrm{~N} \mathrm{fed}^{-1}\right)$ could produce economic wheat grain and straw yields for Sakha 93 in particular, as well as improved soil properties i.e. increased hydraulic conductivity. On the contrary, bulk density, $\mathrm{EC}_{\mathrm{e}}$ and $\mathrm{pH}$ values were decreased.

\section{REFERENCES}

Abedi, T.; A. Alemzadeh and S.A. Kazemeini (2010). Effect of organic and inorganic fertilizers on grain yield and protein banding pattern of wheat. Australian J. of Crop Sci., 4(6): 384-389.

Antoun, L. W.; S. M. Zakaria and H. H. Rafla (2010). Influence of compost, $\mathrm{N}$-mineral and humic acid on yield and chemical composition of wheat plants. J. Soil Sci. and Agric. Engi. Mansoura Univ., 1(11): 1131- 1143.

Asghar H. N.; M. Ishaq; Z. A. Zahir; M. Khalid, and M. Arshad (2006). Response of radish to integrated use of nitrogen fertilizer and recycled organic waste. Pak. J. Bot., 38: 691-700.

Atia, R.H. and K. E. Ragab (2013). Response of some wheat varieties to nitrogen fertilization. J. Soil Sci. and Agric. Eng., Mansoura Univ., 4(3): 309 - 319.

Cheuk W.; K. V. Lo; R. M. R. Branion and B. Fraser (2003). Benefits of sustainable waste management in the vegetable greenhouse industry. J Environ Sci Health 38: 855-863.

El-Hamdi, K. h. H.; A. R. Ahmed and N. E. S. ElAzzony (2012). Effect of compos nitrogen and micronutrient compounds on nitrogen uptake, yield and yield components of wheat. J. Soil Sci. and Agric. Eng., Mansoura Univ., 3(11): 1043 1056.

Harb, O. M. S.; G. H. Abd El-Hay; M. A. Hager; M. K. Hassanien and M. M. Abou El-Enin (2012). Effect of water irrigation quantity and compost rates on some wheat varieties under sandy soil conditions of West Delta region conditions. J. Plant Production, Mansoura Univ., 3(5): 847 - 855.
Jackson, M. L. (1967). "Soil Chemical Analysis." Printic Hall of India New Delhi.

Mahmoud, M. M.; G. H. Youssef and W. M. A. Saddik (2006). Partial replacement of N-mineral requirements by $\mathrm{N}$-organic source as related to both sesame-wheat yields and their components. Egypt. J. Appl. Sci., 21(6B): 12 - 21.

Mansour, S.F (2007). Improving some physical properties of calcareous soils by using diluted sulfuric acid and organic manure .Minufiya. J. Res.,32:553 -562.

Mansour, S.F; A.A.M. Mohamedin and M.M. Mahmoud, (2011. Evaluation of some soil amendments and their applied methods on the reclamation of saline- sodic soils. Journal of Biological Chemistry Environmental Sciences, Vol.6 (4):167-181.

Mariano A.P.; H.R. Sergio; F.A. Dejanira and M.B. Bonito (2009). The use of

vinasse as an amendment to exist bioremediation of soil and ground water contaminated with diesel oil. Brazilian Archives of biology and technology, 4: 1043-1055.

Odlare, M.; M. Pell and K. Svensson (2008). Changes in soil chemical and microbiological properties during 4 years of application of various organic residues. Waste Manag, 28: 1246-1253.

Piper, C.S. (1950). "Soil and Plant Analysis", Inter. Science, Publisher. Inc. Newyork.

Sarwar G.; N. Hussain; H. Schmeisky and S. Muhammad (2007). Use of compost an environment friendly technology for enhancing rice-wheat production in Pakistan. Pak. J. Bot., 39 (5): 1553-1558.

Sarwar G.; N. Hussain; H. Schmeisky; S. Muhammad; M. Ibrahim and E. Safdar (2008). Improvement of soil physical and chemical properties with compost application in rice-wheat cropping system. Pak. J. Bot., 40: 275-282.

Seleem, S.A. and S. M. Abd El-Dayem (2013). Response of some wheat cultivars to nitrogen fertilizer levels. J. Plant Production, Mansoura Univ., 4(5): 721 - 731.

Steel, R. G. D. and J. H. Torrie (1980). Principles and Procedures of Statics. 2nd ed. Mc Graw Hill. International Book Company, New York, USA. 
تاثير التسميد التيتروجينى المعدنى والعضوى على نمو وانتاجية بعض أصناف القمح وعلى بعض صفات الاراضى بشمال الالتا الحسينى المرسى السيد خفاجى التئي معهد بحوث الأراضى والمياه والبيئة ، مركز البحوث الزراعية.

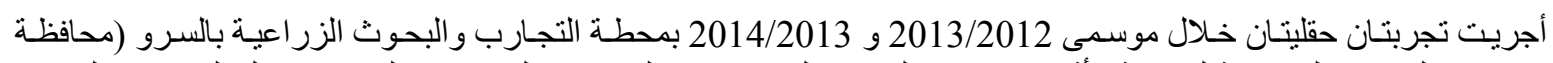

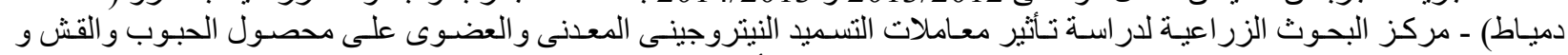

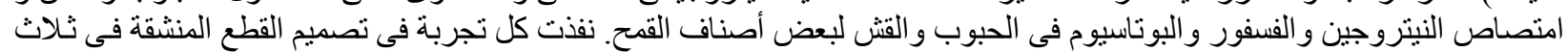

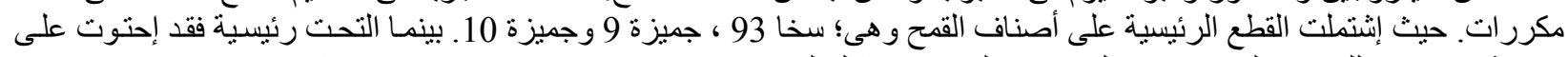

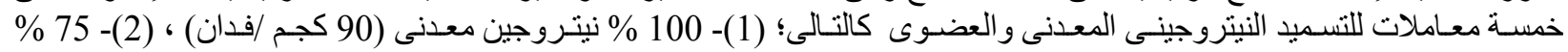

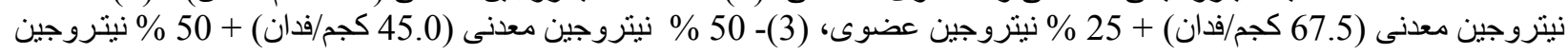

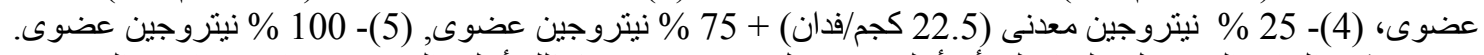

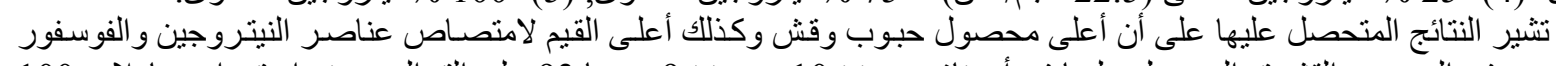

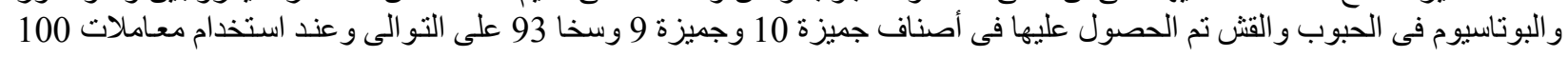

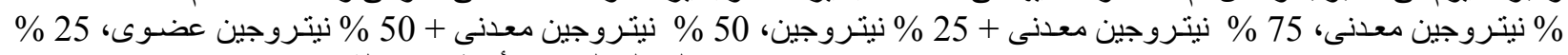

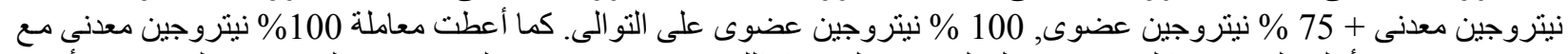

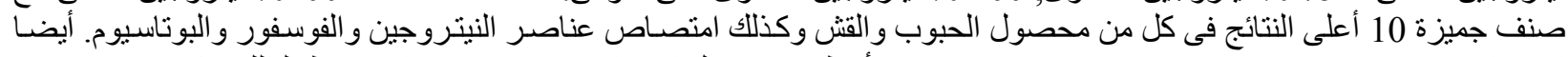

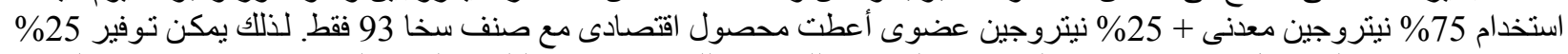

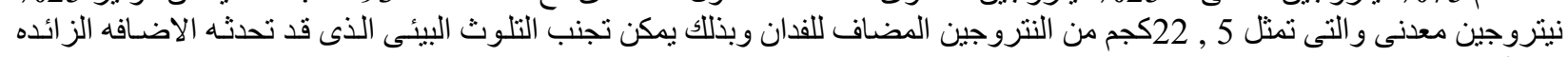

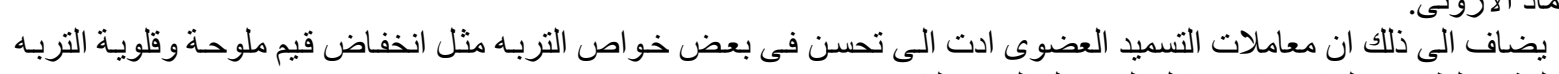
من السماد الازوتى.

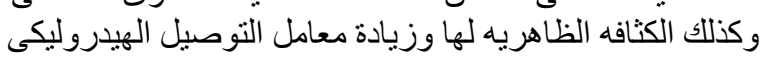

